\title{
Introduction: the citizenship imperative and the political science research methods course
}

\author{
Jeffrey L. Bernstein
}

Almost thirty years ago, when I was applying to graduate school in political science, my senior thesis adviser at Washington University, Charles Franklin, described me in his letter of recommendation (I'm paraphrasing) as someone who thought about politics like a scientist, rather than like some kid who liked politics. I took, and continue to take, these words as a compliment, as I know they were intended. I pursued graduate study out of a desire to take this subject that I had always enjoyed following and to study it with more analytical rigor. ${ }^{1}$ While I had not taken a methodology course as an undergraduate, I had pursued two significant research projects (a seminar paper on African-American voting behavior in Chicago in the 1988 presidential election, and a senior thesis on the re-election rates of freshmen members of the House of Representatives). Approaching politics in a scientific and rigorous manner was, from the beginning of my career, a hallmark of my approach to the discipline; while my go-to approach may have been quantitative, I did develop an appreciation for different research approaches as characterized by people like Richard Fenno (Home Style (1978) was the first of his many books that I devoured), John Kingdon (1989), Robert Lane (1967), and Kristin Luker (1984).

I entered graduate school just as the Wahlke Commission report (1991) was recommending that a research methods course should be a required part of the undergraduate major in political science. When I hit the job market five years later, undergraduate methods courses were still relatively rare. Of the schools where I interviewed, one already had such a course on the books (a "scope and method" course), one was considering creating such a course, and one was less

\footnotetext{
$1 \quad$ When I was seven years old, I had my mother arrange playdates with friends as an opportunity to get into their houses and try to persuade their mothers to vote for Mario Cuomo rather than Ed Koch in the 1977 New York City mayoral primary. My mom thought I was a social kid. She was wrong; I was a political junkie.
} 
than interested in my admittedly self-serving attempts to convince them that such a course would be valuable within their undergraduate curriculum.

In the intervening years, many more departments have followed the guidance of the Wahlke Commission and created an undergraduate course, or courses, in research methods; many of the authors in this volume have been involved in the attempt to implement this requirement, defend it from opponents, or reform it to best fit the needs of their students and departments. A significant body of literature now exists, which catalogues what we know about how to teach the research methods course effectively, and what we still have to learn; the authors here offer a wide range of such references for readers. Differences remain: in this volume, Johan Adriaensen, Patrick Bijsmans, and Afke Groen (Chapter 10), for example, highlight many of these differences both in North America and Europe concerning how we see the course, drawing on the work of Parker (2010), Turner and Thies (2009), and others. Differences over what we should teach in such a course map somewhat (but not entirely) on the qualitative/quantitative divide, and on questions concerning the extent to which the positivist tradition should maintain its hegemony in the discipline. The "Perestroika" debates (see, e.g., Monroe 2005) from the early part of this century remain part of the conversation within the discipline.

As a methodological pluralist at heart, my hope is that these differences will ultimately lead us to value a wide range of research traditions, with an appreciation for what multiple approaches can bring to answering our most vexing research questions. ${ }^{2}$ These conversations are important to have; understanding the methods by which a field constructs knowledge is critical to understanding the field itself. Whatever our research agenda, and whatever the preferred methodological tools we keep in our toolbox, we largely share a desire to look at the political world (broadly conceived), ask questions in an attempt to explain it, and use some systematic method to determine how well our proposed answers work. The methods that a field uses to construct knowledge are an important element in defining the boundaries of that field, which may explain why battles over methodology are among the fiercest within disciplines.

From the perspective of teaching the methods course, these conversations often take the form of disagreement around emphasis, and the struggle to "fit it all in". We have a simple scarcity problem - there is not enough time to teach all that we ideally would like to teach in a single course. ${ }^{3}$ To consider the range of possible topics one might cover, and emphases one might pursue, in a single

2 I've addressed similar desires for a methodological "big tent" in research on the scholarship of teaching and learning in Bernstein (2018).

3 Departments with a two-course methodology sequence are fairly rare. Such a sequence limits, but does not entirely eliminate, the challenges of fitting all we would like to teach into the time available to us. 
introductory class boggles the mind. How much time do we spend on research design (experimental and quasi-experimental design), data collection (ranging all the way from how to do ethnographies and content analysis to surveys), and on data analysis (including the whole range of qualitative and quantitative techniques for data analysis)? Are we teaching a "scope and methods" course, a statistics course, or some hybrid in between? Linked to this, and following Wiggins and McTighe's (2005) principle of backward design, what do we want students to be able to do when the course ends? Should they be capable of explaining and analyzing the literature in the field, or should they be able to produce their own research paper? If the latter, what methods should they be capable of using for their analysis? Knowing where we want them to end up, of course, can be vital in our decisions about how to structure a course to get them there.

From a pedagogical perspective, one of my overarching goals when I teach our department's research methods class is to inculcate students into our discipline, and help to move them along the path to "thinking like political scientists". Wineburg's (2001) provocative work on differences in historical thinking between expert historians and novice history students reveals significant differences in how both groups approach a collection of historical documents in their attempts to answer a historical puzzle. ${ }^{4}$ The good news, however, is that the skills practiced by the experts can be identified and taught to students. In Wineburg's study, these skills included paying close attention to the source of a particular document, reading the documents in the order in which they were produced, and using the documents almost in conversation with one another in an attempt to interrogate the truth. Learning these skills, in and of themselves, helps students toward emulating the practices of professionals in their disciplines.

We cannot expect one course, or even an entire undergraduate program, to have students thinking like political science professors. But we can, as Bain (2008) puts it, uncover the invisible cognitive processes in which professionals in the discipline engage. To this end, just as students take our substantive classes so they can learn about international security politics, or about the politics of the developing world, we should encourage them to take methodology courses so they can learn how we go about answering important questions in the discipline. Teaching undergraduate political science students means not just teaching them what we know, but also teaching them how it is that we have come to know what we know.

4 The expert vs novice literature in history is more extensive than that of political science, and I draw from that work here and elsewhere. For a modest attempt to explore this approach in political science, see Bernstein (2010). 


\section{MAXIMIZING THE EFFECTIVENESS OF UNDERGRADUATE METHODS TRAINING}

This volume aims to contribute to the conversation about the research methods course in two distinct ways. First, we focus here on different ways to teach the specific course effectively - for example, how to work with students on finding good research topics, or how to help students learn to write literature reviews, or work through issues of concept definition and measurement. At this level, I hope the interested reader will be able to find techniques for teaching many of the course concepts and be able to pull them out of this book and apply them in their own courses. A second category of chapters considers how the methods course fits within the broader framework on the discipline. How do we avoid sequestering the methods course into its own silo, requiring such a course but offering students little justification for such a requirement? How can we maximize the effectiveness of this course within the undergraduate programs of our students?

One question we might address is when the methods course should ideally be taught (see Bergbower 2017 for a useful discussion on the topic). Like many of the authors in this volume, I would like to see it come early in the major - perhaps after some introductory courses are taken, so that the students can understand some basics of the discipline, but early enough so that students can apply what they have learned in the class to future courses within the subfields of our discipline. An additional reason for taking the class in this sequence is to plant the seeds early on for students to begin thinking about potential thesis topics, or even research questions they might explore in their upper-level classes, should they decide to follow this route.

This approach presupposes two separate, but important, considerations. First, it requires that the research methods course be interesting and engaging enough so that we do not lose students. Zsolt Nyiri (Chapter 1) and others here note that students come to us because they are deeply engaged in political issues, whether these issues be abortion, immigration, or the environment. They want to learn more about these issues, thereby enhancing their skills as advocates for the policy change they wish to see. What they learn in their introductory survey courses might touch the surface of these important issues, but will undoubtedly leave them wanting and ready for more. And then, we bring them into the methodology course - where they are confronted with conceptual definitions, literature reviews, t-tests, and regression coefficients. To say the least, we risk losing their interest at this point; moreover, since most students by this point have taken few courses in the major, we may risk losing them (and their student credit hours) to other departments. 
Ideally, we are already thinking about each of these considerations as we teach the courses. None of us teach the methods course with an interest in boring students, or in turning them off from future study in political science. Even if we teach subjects that students might not find interesting, there are helpful approaches we can take to sharing our course material with students in the most interesting way possible. A study of the t-test would interest few of us; explorations of potential gendered reactions to candidate appearance that use t-tests is much more engaging, and will leave students thinking deeply, and perhaps even imagining what future work on the subject should be like. ${ }^{5}$ Discussions of experimental and quasi-experimental design, and internal and external validity, may not be over-stimulating to most students, but linking this to engaging content (such as Iyengar and Kinder's (1987) classic experimental work on the agenda-setting power of TV news) can get students using these terms with ease as they consider the substantive findings, how the research design helped to drive these results, and how these results may or may not be dependent upon the time in which the study was done.

Many of us struggle to make concept definition and measurement seem interesting to our students; such readers would do well to consult some of the examples in this volume. Kristin Makszin (Chapter 4) addresses measurement challenges through her engaging (and fun!) example about her invisible pet, while Amanda M. Rosen (Chapter 6) teaches conceptual definition through having her class consider at length the operational challenges involved in determining where one can find the Best Breakfast in Town. For Jason Enia (Chapter 5), the entire course presents opportunities to step away from dry lectures on the subject and instead to simulate the kinds of challenges experienced practitioners of research face on a daily basis. In each of these cases, the authors seek to make the study of research methods more engaging, more practical and, dare we say it, even more fun for their students.

Even the teaching of statistics, the bane of the existence of most of our students (Bernstein and Allen 2013; Oldmixon 2018), can be done in an engaged manner. Michael A. Bailey (Chapter 7) argues that by streamlining how we teach statistics, we can get to the more interesting material more quickly, and get the students working on substantively interesting questions sooner. I have seen this work in my own experience teaching the course - giving students the variation in a substantively interesting variable to explain, and the tools of regression with which to craft this explanation, students are able to do interesting work sooner, even if they may lack the detailed statistical understanding

5 To this end, I have had success using Hayes et al. (2014) to generate these kinds of discussions in my class; the article is quite accessible and engaging for students. 
of the mathematical foundations of the regression model (we should save something for graduate school!). And, while Matthew C. Ingram's (Chapter 8) work on transparency and reproducibility, done in a purely statistics course, might be beyond what we can do in a one-semester comprehensive methods course, his work highlights a critical lesson for teaching methodology: keeping detailed syntax files and tracking one's work carefully, as he advocates, reinforces that statistical analysis is part of a conversation among scholars. We don't use statistics for the purpose of completing a problem set and then walking away - statistical analysis is one important way that political scientists explore, refine, share, and discuss our emerging understandings of how substantively interesting variables interact with one another. Thinking of this part of the course in this way might (perhaps I am too optimistic!) help students to appreciate why we put them through this torture.

The research methods course is not only the course students dread taking the most; it is also often the one that most interferes with their progress toward completion of the degree. William D. Blake and Carolyn Forestiere (Chapter 13) offer us a glimpse at how their department confronted the challenge of low performance in the class, and how intentional course changes have helped to improve their situation. Moreover, as we consider increasing moves toward online education, both predating and influenced by COVID-19, I am grateful for Robert Postic's work (Chapter 9), which demonstrates that careful attention to student learning can yield positive results when we offer these courses online, belying the concerns of some that these courses cannot possibly be taught as effectively in this manner.

If we decide it makes sense to teach the methodology course relatively early on in the students' journey through our discipline, this suggests a need to embed the course content more fully in the curriculum. Kelly A. Clancy and Kelly Bauer's approach (Chapter 11) to embedding methods across their departmental curriculum strikes me as highly effective and ambitious, perhaps only possible in a small and nimble department, but it seems well worth our effort to at least make a move in the direction that their department has taken. We might consider the methods course to be like the proverbial gun in a stage play: if it makes an appearance in Act I of the major, then we should definitely endeavor to use it in Act II.

One intriguing area, which strikes me as a reasonable fulcrum around which methods courses revolve, is information literacy. Amanda Shannon and Vaughn Shannon (Chapter 2) explore ways that a particular course can enhance the information literacy skills of students; their model of embedding a librarian within classes (see also Shannon and Shannon 2016) offers a highly efficacious approach to leveraging information literacy skills within the course. Going a step beyond that, Christi Siver and Claire Haeg (Chapter 12) consider how we can embed information literacy within the entire political 
science curriculum. Their model of incorporating questions of information literacy into a range of courses, from the introductory level all the way to upper-level research courses, is provocative to ponder, and represents an exciting model for how we can help to improve civic discourse by making our students stronger at understanding the sources of input they receive in the political world.

Incorporating a methods course into the curriculum may be a harder nut to crack than is teaching a single methods course effectively, as we rely on our colleagues to incorporate methodological material into their courses in order to achieve our goal. In an ideal world, a department will unite around a desire to connect the methods course to other courses in the department, and create a spiraling effect where the methods courses reinforce what is being learned in the more topical courses, which in turn reinforce what is being learned in the methods courses. This appears to be the case for Kelly A. Clancy and Kelly Siver Bauer, and for Christi Silver and Claire Haeg, who teach in smaller, more agile departments than many of us do.

Even in larger, more staid departments, I would argue that merely incorporating a few such discussions into substantive courses would make a significant difference. A public opinion course, for example, could share survey data about individual attitudes toward abortion, and supplement that discussion with interview data (such as from Kristin Luker's Abortion and the Politics of Motherhood (1984)) to address different understandings of public opinion that arise from closed-ended surveys versus intensive interviews. A comparativist might teach material based on the author's fieldwork (or even discuss their own) and compare different approaches to data-gathering (perhaps elite interviews versus immersion in local villages) for understanding any political phenomena being studied (see Kapiszewski et al. 2015 for methodological discussions around field research). Even small steps - perhaps one or two discussions devoted to the research methodologies used by the authors being studied in a given course - will help students see the continued value of research methods coursework as they move through their program.

\section{THE CITIZENSHIP IMPERATIVE}

I will conclude this Introduction by advocating that we incorporate citizenship education as a frame for political science research methods courses. An effective methodology course in political science, in concert with the rest of the courses in the major, can help our discipline fulfill its traditional civic mission and mandate. In so doing, I would suggest that there are (at least) three critical aspects of citizenship that we ought to endeavor to impart to our students: (1) developing a comfort with data and how it can be used to make and assess claims; (2) developing a comfort with ambiguity and uncertainty in the ques- 
tions we ask; and (3) developing an appreciation for the value diverse people and diverse perspectives add to our understanding of the civic world.

One important piece of being an effective citizen is understanding how to evaluate claims being made by public officials. Websites like Snopes, or PolitiFact, can separate the true statements from the false. But most statements that are interesting, and worthy of serious consideration by scholars, are more complex, and require more than a simple "True" or "False" (and, in fact, even these fact-checking websites often are unable to render a statement wholly true or wholly false). A methods course, when done well, teaches students to look closely at the data (whether the data be individual narratives, or large- $\mathrm{N}$ datasets). It also teaches students to consider the universality of claims: do all of our arguments apply to all units of analysis equally, or are different causal mechanisms at work across different units? What data are believable, and what data require further confirmation or consideration?

To take just one range of examples, voters casting a vote in a presidential election need to grapple with economic data - is the economy strong, or is it weak? This opens up multiple methods-related questions, such as how do we measure the strength of the economy? We should also ask: to which narratives we should listen when considering whether people are better off now than they were four years ago? Whose voices are heard, or ignored, as the state of the economy is reported by the media, or by friends on Facebook? How are we to understand fluctuations in job gain/loss numbers as being some part signal, but also some part noise? It would be too much to ask that our students understand all of this - truth be told, many of us struggle with these concepts in our own political decision-making. But thinking about measurement, about how to weigh competing narratives, and about statistical variability, are the kinds of topics we can address in our methodology courses. Such comfort with data, and an ability to apply this knowledge to different contexts they face as voters, will make our students more effective civic participants.

A second critical disposition of citizenship is the development of comfort with, and perhaps even joy in, ambiguity. Facts may be facts, and data may point us clearly in some directions in certain cases. But in many other areas, there is no single, simple, straightforward conclusion to be drawn. Shane Nordyke and Peter Yacobucci's (Chapter 3) exercise in developing literature reviews, including a focus on different "camps" and scholarly clusterings in research, reminds us (and our students) that very smart people, focusing on the same area of scholarship, can reach different, defensible conclusions on what it all means. Perry's (1970; see also Belenky et al. 1986) pioneering work in education psychology teaches us that college students advance along a continuum from dualism (in which one unambiguous Truth is dispensed by a wise Authority) through multiplicity (in which each different viewpoint is considered equal and valid) to relativity (in which we gain the ability to weigh 
the merits of different positions and reach our own informed conclusions). Exercises such as those used by Nordyke and Yacobucci help move students along this path. Among other examples, Amanda M. Rosen (Chapter 6) does this as well, as students wrestle with the unanswerable question of where to find "The Best Breakfast in Town", and learn that this answer is driven, in part, by how the question is framed and concepts defined.

The scientific study of politics does not always provide us with simple answers; how many of us, for example, respond to students' desires for a yes/ no response with "It depends" or "We really are not sure"? These answers can frustrate students; some of them, perhaps showing signs of Perry's dualism, may be unhappy with us and think we're withholding the true answer. Most of the people reading this book, however, will recognize questions and answers like these as being exciting and germinative. How many of us developed our dissertation topics, or other research projects, by asking these kinds of difficult questions, finding no simple answer, and heading over to the library for the next five years? Can we convince students this is fun? Probably not, at least in the vast majority of cases. But I do believe we can teach them that embracing ambiguity is very much a part of understanding the world, and understanding the difficulties that confront us as we seek to act in the civic environment.

A third critical piece of citizenship requires an understanding of diversity, and the impact such considerations have on society. We are not all alike, we do not all think the same way, and those who look different from us, think differently from us, and value outcomes differently from us are worthy of consideration as we attempt to understand the political world. I do not make this point to suggest that all views and perspectives are equal and deserve a seat at the table; I do not wish to invite white supremacists, to name just one example, to sit at the table with me. However, for anyone attempting to understand our political system, and the outcomes it produces, we must understand the views of those who differ from us, and to include them in our models of how the system explains things. Cramer (2016) provides a very powerful example of how her knowledge of the views and thought patterns of rural Wisconsinites helped her to understand the 2016 election in a way that many of us lacking that knowledge could not, and did not.

Achen (2014) offers a cogent argument for why a statistical concept (the use of interaction terms in multivariate models) is really an argument about diversity (considering being a woman, or racial minority, not as an add-on to a model, but rather as an indication that for some people, their identity affects how other variables behave in the model). While the statistical piece of the argument is beyond where some of our methods courses can go, the substance of it should not be. We see this clearly reflected in this book, as Harwood K. McClerking (Chapter 14) and Alexis Leanna Henshaw (Chapter 15) both discuss how much more limited our knowledge of the field is when we do not 
listen to other voices clamoring to be heard. Studying African-Americans, or studying women, without in any way changing the tools we pull out from our methodological toolkit, makes us poorer political scientists, and poorer instructors of political methodology classes.

In the end, I join Jonathan B. Isacoff and the Deweyan perspective he so expertly shares (Chapter 16), along with Alexis Leanna Henshaw, Harwood $\mathrm{K}$. McClerking, and so many of the other authors of this book, in arguing that teaching and learning in political science research methods must be oriented around citizenship, and around ways to improve the human condition and reduce suffering. I do not suggest, of course, that a well-run ANOVA will end hunger, or that a carefully done literature review will bring lasting peace to the Middle East. But, as we look out at the students in our classroom, I would urge us to see them as political science students, but also as current and future civic actors. They confront a world that in many ways has lost its way, and they will face epic challenges in attempting to save the planet, fight racism, end other forms of suffering, and try to build their future. The political science research methods class becomes more than just another boring class (or worse) when we explicitly find ways to connect what we teach to what our students need to learn in order to be future leaders, and to address the challenges they will face going forward.

\section{REFERENCES}

Achen, Christopher. 2014. "Why Do We Need Diversity in the Political Methodology Society?". The Political Methodologist. Accessed 30 September 2020 at https:// thepoliticalmethodologist.com/2014/04/30/we-dont-just-teach-statistics-we-teach -students/.

Bain, Robert B. 2008. "Into the Breach: Using Research and Theory to Shape History Instruction". Journal of Education 189 (1/2): 159-67.

Belenky, Mary Field, Blythe McVicker Clinchy, Nancy Rule Goldberger and Jill Matuck Tarule. 1986. Women's Ways of Knowing: The Development of Self, Voice, and Mind. New York: Basic Books.

Bergbower, Matthew L. 2017. "When are Students Ready for Research Methods? A Curriculum Mapping Argument for the Political Science Major". Journal of Political Science Education 13 (2): 200-210.

Bernstein, Jeffrey L. 2010. "Using Think-Alouds to Understand Variations in Political Thinking”. Journal of Political Science Education 6 (1): 49-69.

Bernstein, Jeffrey L. 2018. "Unifying SoTL Methodology: Internal and External Validity". Teaching and Learning Inquiry 6 (2): 115-26.

Bernstein, Jeffrey L. and Brooke Thomas Allen. 2013. "Overcoming Methods Anxiety: Qualitative First, Quantitative Next, Frequent Feedback Along the Way”. Journal of Political Science Education 9 (1): 1-15.

Cramer, Katherine J. 2016. "For Years, I've been Watching Anti-Elite Fury Build in Wisconsin. Then Came Trump". Published 16 November 2016 at http://www.vox .com/the-big-idea/2016/11/16/13645116/rural-resentment-elites-trump. 
Fenno, Richard F., Jr. 1978. Home Style: House Members in their Districts. Boston, MA: Little, Brown.

Hayes, Danny, Jennifer L. Lawless and Gail Baitinger. 2014. "Who Cares What They Wear? Media, Gender, and the Influence of Candidate Appearance". Social Studies Quarterly 95 (5): 1194-212.

Iyengar, Shanto and Donald R. Kinder. 1987. News That Matters: Television and American Opinion. Chicago, IL: University of Chicago Press.

Kapiszewski, Diana, Lauren M. McLean and Benjamin L. Read. 2015. Field Research in Political Science: Practices and Principles. Cambridge: Cambridge University Press.

Kingdon, John W. 1989. Congressmen's Voting Decisions (3rd edn). Ann Arbor, MI: University of Michigan Press.

Lane, Robert E. 1967. Political Ideology: Why the American Common Man Believes What He Does. New York: Free Press.

Luker, Kristin. 1984. Abortion and the Politics of Motherhood. Berkeley, CA: University of California Press.

Monroe, Kristen Renwick (ed.). 2005. Perestroika! The Raucous Rebellion in Political Science. New Haven, CT: Yale University Press.

Oldmixon, Elizabeth A. 2018. "'It Was My Understanding That There Would Be No Math': Using Thematic Cases to Teach Undergraduate Research Methods". Journal of Political Science Education 14 (2): 249-59.

Parker, Jonathan. 2010. "Undergraduate Research Methods Training in Political Science: A Comparative Perspective". PS: Political Science \& Politics 43 (1): $121-5$.

Perry, William G., Jr. 1970. Forms of Intellectual and Ethical Development in the College Years: A Scheme. New York: Holt, Rinehart, and Winston.

Shannon, Amanda and Vaughn Shannon. 2016. "Librarians in the Midst: Improving Student Research Through Collaborative Instruction". Journal of Political Science Education 12 (4): 457-70.

Turner, Charles C. and Cameron G. Thies. 2009. "What We Mean by Scope and Methods: A Survey of Undergraduate Scope and Methods Courses". PS: Political Science \& Politics 42 (2): 367-73.

Wahlke, John C. 1991. "Liberal Learning and the Political Science Major: A Report to the Profession". PS: Political Science \& Politics 24 (1): 48-60.

Wiggins, Grant and Jay McTighe. 2005. Understanding by Design (2nd edn). Alexandria, VA: Association for Supervision and Curriculum Development.

Wineburg, Sam. 2001. Historical Thinking and Other Unnatural Acts: Charting the Future of Teaching the Past. Philadelphia, PA: Temple University Press. 